\title{
SATIRE POLITIK DALAM LAGU \\ "ANDAI KU GAYUS TAMBUNAN"
}

\author{
Dyan Rahmiati \\ Dosen IImu Komunikasi Fakultas IImu Sosial dan IImu Politik Universitas \\ Brawijaya
}

\begin{abstract}
Abstraksi
Lagu mampu menyampaikan sebuah pesan sosial secara menarik, dengan kemasan menghibur dan mampu diterima secara lebih general membuat lagu mampu bergerak dalam proses pemberian pesan penyadaran sosial. Kekuatan ini semakin lengkap ketika isu-isu sensitif terutama yang berkaitan dengan kekuasaan dikemas dalam bentuk satir.

Kehadiran sosok Gayus Tambunan menjadi fenomena menarik, karena keberadaannya menjadi trigger atas masalah sosial dan politik di negara ini. Korupsi, sebuah kondisi sosial yang ternyata hingga kini belum hilang walaupun pemerintah mencanangkan untuk memberantas perilaku negatif. Dengan diangkatnya wacana ini ke permukaan, menjadi sebuah bukti akan pertanyaan besar korupsi masih menjadi mitos negeri ini. Semakin marak ketika ketidakadilan akan perlakuan hukum bagi kelompok marginal.

Pesan satir politik melalui lagu mampu memberi teguran sarat kritik dengan sisipan kemasan humor lebih mengena. Menurut Freud, tampilan jenaka dimaksudkan untuk mengungkapkan tekanann terhadap musuh, mengajak orang lain untuk mentertawakan musuh kita. "By belittling and humbling our enemy, by scorning and ridiculing him, we indirectly obtain the pleasure of his defeat by the laughter of the third person, the inactive spectator."

Objek satir dalam lagu ini bukan hanya Gayus Tambunan sebagai pribadi namun lebih pada siapa saja yang diwakili olehnya, instansi, kejaksaan, pemerintah bahkan siapa pun yang mandapatkan keuntungan atas ketidakadilan sistem politik dan hukum di negeri ini.
\end{abstract}

Kata Kunci: Satire,Lagu, Politik. Gayus Tambunan 


\section{Musik Sebagai Media}

Wherever there's power, there's satire to mock it.

Wherever there's satire, the censors will block it.

And where there are censors, satirists fight 'em,

The battle continues, ad infinitum

(Freedman, Leonard. 2009)

Musik merupakan perilaku sosial yang kompleks dan universal yang didalamnya memuat sebuah ungkapan pikiran manusia, gagasan, dan ide-ide dari otak yang mengandung sebuah sinyal pesan yang signifikan. Pesan atau ide yang disampaikan melalui musik atau lagu biasanya memiliki keterkaitan dengan konteks historis. Muatan lagu tidak hanya sebuah gagasan untuk menghibur, tetapi memiliki pesan-pesan moral atau idealisme dan sekaligus memiliki kekuatan ekonomis.

Sejak tahun 1998 negara Indonesia mengalami sebuah perubahan yang sangat penting dalam kancah perpolitikan nasional. Dengan bergulirnya reformasi mampu membuka kran demokrasi di negara ini. Kebebasan untuk mengemukakan pendapat yang merupakan inti dari wacana demokrasi diekspresikan dalam beragam bentuk, dintaranya kebebasan informasi.

Masyarakat Indonesia semakin kaya dengan wacana tentunya dengan dukungan informasi yang mudah sekali diperoleh. Wacana sosial politik negeri ini bukan lagi milik segelintir orang, semakin banyak masyarakat yang 'melek' isu-isu sosial politik. Kesemuanya tidak lepas dari dukungan media massa, baik konvensional maupun new media. Keterlibatan masyarakat dalam berpendapat di bidang politik tentunya membawa angin segar bagi demokrasi politik Indonesia. Seiring dengan semakin banyak masyarakat yang mengerti informasi, diharapkan fungsi kontrol masyarakat terhadap pemerintah dan actor-aktor dan institusi pemerintahan di negara ini semakin besar dan berkembang.

Media merupakan alat bantu untuk mentransmisikan informasi dan isi simbolik. Secara intrinsic merujuk pada banyak hal sehingga mau tidak mau bersentuhan dengan dunia politik. Media massa menangkap fenomena sosial, politik dan fakta di masyarakat dan mengemasnya dalam bentuk berita, artikel, foto jurnalistik, maupun sindiran-sindiran dari tingkatan ringan hingga berat. ${ }^{1}$ Politik berkaitan dengan kekuasaan, sehingga seringkali bahasan mengenai tema politik ini karena bersinggungan dengan penguasa, maka penyampaiannya lebih memiliki makna tersembunyi. Media yang digunakan

\footnotetext{
${ }^{1}$ Chris Barker, Cultural Studies Teori dan Praktek, (Yogyakarta: Kreasi Wacana, 2009), hal. 16
} 
untuk mengekspresikan nasionalisme beragam dari media massa konvensional (televisi, radio dan surat kabar) hingga internet, namun satu yang pasti semuanya dalam bentuk satir, mengekspresikan kejujuran akan apa yang dirasakan sekaligus kemarahan terhadap situasi. Kekecewaan atau kritikan terhadap sesuatu atau seseorang yang memiliki kekuasaan tidak serta merta bisa diungkapkan secara terbuka dan gamblang.

Pengungkapan dalam kemasan yang lebih ringan, dengan humor menjadi cara yang dianggap efektif. "Only jokes that have a purpose run the risk of meeting with people who do not want to listen to them". Alasan memilih humor adalah sebagai cara protes sosial, sebab sesuai dengan kepribadian tradisional bangsa kita yang tidak suka dikritik secara langsung. Dengan adanya sikap ini, maka di negara kita, protes tidak langsung mempunyai pengaruh yang lebih ampuh dibandingkan dengan protes yang langsung. Protes sosial dalam humor tidak mungkin ditanggapi secara serius, karena yang menyuarakan sama sekali tidak bertanggung jawab. Tanggung jawab dalam protes sosial berupa humor sudah diambil kolektif; sehingga tanggung jawabnya pun secara kolektif.

Gaya penyampaian semacam itu dinamakan satir. Satire merupakan gaya bahasa yang dipakai dalam kesusastraan untuk menyatakan sindiran atau ejekan terhadap suatu keadaan atau seseorang. Political satire adalah bagian dari satire yang khusus mengambil sisi hiburan dari sebuah fenomena politik. Digunakan pula dalam pidato politik untuk mengungkapkan pesan secara implicit, seperti pada saat 'menyerang' lawan politik dengan menggunakan kata-kata sindiran. Pesan satir bisa diwujudkan dalam beragam bentuk, karikatur, tulisan, karya sastra, maupun karya seni termasuk didalamnya adalah lagu. ${ }^{2}$

Pembuat pesan satir menurut Max Beerbohm, "a fellow laying about him lustily, for the purpose of hurting, of injuring people who, in his opinion, ought to be hurt and injured.". yang perlu digaris bawahi adalah pesan satir ini memang dimaksudkan untuk menyakiti orang yang dituju, hanya saja dengan simbolsimbol yang kerap memiliki makna implisit. Pesan satir ini selalu menggunakan 'humor' sebagai senjata menjatuhkan, sangat mengena bagi orang atau sesuatu yang dimaksudkan dalam pesan satir tersebut namun memberikan hiburan bagi orang lain yang membaca pesan (the third person).

Satirist lebih tidak eksplisit terhadap doktrin politik mereka, sehingga apabila ingin mengetahui keberpihakan mereka maka kita harus melihat pesan satir yang dihasilkannya. Perspektif politik satirist tercermin lebih pada apa yang mereka tentang atau tidak setujui dari Fenomena sosial yang ada tersebut bukan hanya pada untuk tujuan apa mereka ada. Memberikan pesan politik secara implisit dengan atau dalam bentuk hiburan, namun biasanya orang yang

${ }^{2}$ Leonard Freedman, The Offensive Art, Political Satire and Its Censorship around the World from Beerbohm to Borat, (London: Praeger Publishers, 2009), p. 68 
tertawanya paling keras atau yang paling merasa terhibur adalah mereka yang berseberangan lini, pandangan dan pendapat dengan objek satir.

\section{Lagu, Jembatan Pemikiran}

Melalui musik mampu menembus batasan, bisa dinikmati oleh semua orang yang mendengarkan. Simbol general yang memiliki keleluasaan dalam ruang lingkup isi, karena tidak dibebani oleh aturan-aturan tertentu. Meski fungsi hiburan dari sebuah lagu sangat dominan, namun sesungguhnya bisa disisipi oleh tujuan lain dari penciptanya. Dari fungsi media massa yang melekat pada sebuah karya, fungsi transmisi,sosialisasi dan edukasi merupakan fungsi yang memiliki posisi strategis dan menunjukkan kekuatan dari lagu sebagai bentuk media penyampai pesan pada khalayak. Melalui fungsi transmisi, lagu mampu mewariskan norma-norma dan nilai-nilai tertentu pada masyarakat, termasuk sebagai upaya penyadaran akan fenomena tertentu.

Konsekuensinya adalah peran ideologis lagu, perlawanan terhadap penguasa, atau pihak-pihak yang memiliki kekuasaan dengan mengkritisi atau bahkan melakukan perlawanan terhadap ideologi dominan. Ruang gerak dari karya seni yang luas menyebabkan pambuat karya seni tersebut mampu menyampaikan kritik, maupun perlawanan dengan cara yang halus, melalui metafora-metafora, perumpamaan, penokohan, alur, dan unsur-unsur lain yang bisa ditampilkan dengan lebih bebas dan relatif lebih 'aman'. ${ }^{3}$

Kemampuan melihat persoalan bangsa bukan hanya dimiliki kaum politisi, kaum seniman juga mempunyai kemampuan yang sama dengan bahasa yang berbeda. Jika para politisi bisa memprediksi persoalan kebangsaan dari analisa politik, sebagai seniman juga bisa bicara bangsa dari analisa-analisa kultural, atau kesenian. Musik sebagai hiburan juga harus memberi pencerahan dengan lirik atau lagu yang berjiwa dan bermakna bagi kehidupan. Dalam berkesenian seorang seniman tidak boleh memalingkan diri dari realitas sosial. Bahkan musik bisa berfungsi sebagai kontrol sosial.

Di era industri musik, kritik sosial yang menyorot kepincangankepincangan sosial juga banyak ditemui, seperti pada lagu-lagunya Iwan Fals, Franky Sahilatua, Leo Kristi, Gombloh, Harry Roesli, Mogi Darusman, God Bless, Swami, Kantata Takwa, atau Slank. Bahkan di era penguasa Orde Baru sangat represif terhadap kritik seni, Lagu-lagu bernada kritik sosial tak jarang mengalami pencekalan, disensor dengan alasan dapat mengganggu stabilitas politik. Namun seiring dengan dibukanya kran demokrasi, maka semakin banyak pula hasil budaya yang menyuarakan kritik sosial yang dikerjakan secara

${ }^{3}$ Griffin. Dustin H, Satire: A Critical Reintroduction Dustin Griffin. Satire: A Critical Reintroduction, (Lexington: University Press of Kentucky, 1994), p.77 
profesional maupun melalui musik indie. Seperti diungkap oleh Plato, musik bukan saja berpengaruh dalam kehidupan juga bisa menjadi pilar kekuatan kehidupan demokratisasi.

Sebagai bentuk kreativitas seni, kehadiran musik bertema kritik sosial, mengulas ketimpangan-ketimpangan yang terjadi dalam prinsip-prinsip umum kehidupan masyarakat misalnya ketidakadilan dan keprihatinan atas kondisi realitas sosial. Album Perahu Retak (Franky Sahilatua \& Emha Ainun Nadjib), adalah salah satu contoh ungkapan keprihatinan yang menyorot ketidakadilan dan ketimpangan sosial terjadi di negeri ini. Album Iwan Fals bertajuk Manusia $1 / 2$ Dewa yang dirilis saat Pemilu 2004 banyak mengangkat tema sosial politik. Contoh lain yang sarat kritik sosial tak kalah dasyatnya adalah lagu Gosiip Jalanan milik Slank. Lagu yang dinyanyikan kelompok musik Slank menyorot masalah terjadinya korupsi di intitusi pemerintah. Fenomena kritik sosial dalam lagu berulang kembali dalam lagu Andai Aku Gayus Tambunan, kali ini mensoroti ketidakadilan hukum di Indonesia.

\section{Pesan Satir dalam lagu “Andai Ku Gayus Tambunan”}

Lagu "Andai Ku Gayus Tambunan" karya Bona Paputungan diposting di Youtube pada bulan Januari 2011. Lirik lagunya sarat dengan pesan satir, memotret kehidupan politik, kondisi hukum di Indonesia lewat kata-kata. Nama Gayus Tambunan, seorang mantan pegawai negeri sipil di Direktorat Jenderal Pajak Kementerian Keuangan Indonesia mencuat ketika Komjen Susno Duadji menyebutkan bahwa Gayus mempunyai uang Rp 25 miliar di rekeningnya plus uang asing senilai 60 miliar dan perhiasan senilai 14 miliar yang didapatkan dari hasil korupsi, sehingga memunculkan konsep Mafia Pajak.

Satir merupakan sebuah ungkapan ironi, sebuah tragedi yang dibungkus dalam sebuah komedi sehingga bersifat parodi. Bukan menjadi hal yang aneh apabila muatan satir tersebut memiliki kejanggalan yang bisa menertawakan namun memiliki makna memprihatinkan. Pesan satir yang dilekatkan dalam sebuah lagu mampu diterjemahkan secara mudah namun karena ke-jenaka-an nya maka akan mampu meminimalisir konflik yang bisa saja muncul. Mengggunakan tampilan humor sebagai senjatanya mengungkapkan pesan satir. Menurut Freud, tampilan jenaka dimaksudkan untuk mengungkapkan tekanann terhadap musuh, mengajak orang lain untuk mentertawakan musuh kita. "By belittling and humbling our enemy, by scorning and ridiculing him, we indirectly obtain the pleasure of his defeat by the laughter of the third person, the inactive spectator."

Kritik sosial dalam lagu, seperti yang sudah diungkapkan sebelumnya sudah sering ditampilkan, namun lagu "Andai Ku Gayus Tambunan" mengemasnya dalam bentuk yang berbeda, dengan sentuhan humor dari sisi 
visual nya dan lirik lagunya. Mudah untuk dipahami dengan sederhana. Lagu "Andai Ku Gayus Tambunan" diawali dengan lirik lagu yang mencerminkan keadaan sebenarnya yang dirasakan seorang narapidana. Menampilkan kelompok marginal yang tidak memiliki kekuatan untuk melakukan sesuatu kecuali menerima keadaan.

Diawali dengan visualisasi di balik jeruji penjara yang gelap dan sempit, mengandung makna keterbatasan, tidak bebas melakukan apapun hal-hal yang diinginkan. Efek suara natural memberikan kesan dramatis. Hanya diiringi alat musik tunggal, gitar, lagu ini mengalun sederhana tapi sarat makna. Justru dengan tampil tampak apa adanya tersebut, semakin menunjukkan pesan kejujuran melihat sebuah realitas yang direpresentasikan dalam lagu.

Sebuah fenomena sosial di Indonesia yang tidak mencerminkan sifat keadilan ditampilkan dalam lirik "Lucunya di negeri ini, Hukuman bisa dibeli, kita orang yang lemah, Pasrah akan keadaan". Hukum di Indonesia yang tidak berasaskan keadilan inilah yang kemudian dianggap sebagai penyebab. Pesan kekecewaan akan kondisi penerapan hukum di Indonesia diaplikasikan kedalam bentuk satire dianggap sebagai komunikasi tidak langsung dalam mengungkapkan suatu kondisi atau pun kritik sosial, tetapi dalam pengungkapannya harus menggunakan ironi.

Ironi Visual yang ditampilkan menunjang pesan satir, setelah memberikan imbalan, si narapidana berhasil keluar dengan mudahnya, sementara yang lain tahu namun tidak bisa berbuat apa-apa dan tidak memiliki pilihan. "...Kita orang yang lemah, Tak punya daya apa-apa, Tak bisa berbuat banyak, Seperti para koruptor... " para koruptor diletakkan pada posisi dominan, berdaya karena mampu berbuat banyak hal. Bahkan fasilitas-fasilitas tambahan diberikan pada tokoh yang memerankan Gayus Tambunan, dibekali kostum untuk melakukan penyamaran dan kendaraan yang tidak mungkin akan didapatkan mereka yang tidak memiliki kekuasaan.

Kekuatan visualisasi membantu membentuk frame audiens akan pesan yang disampaikan. Interpretasi adalah sebuah proses pemberian arti dan pemahaman terhadap pengalaman, artinya audiens akan menginterpretasi tanda yang secara fisik diterima kemudian dikaitkan dengan pengalamannya akan tanda yang berkaitan. Charles Osgood dengan Model Coding, menyatakan pengartian adalah asosiasi yang sederhana antara sebuah simbol atau rangsangan dan pengertian tentang sesuatu, tetapi dalam komunikasi manusia pengartian lebih kompleks dari itu (karena juga melibatkan maksud-maksud dari komunikator). Orang menghasilkan pesan bukan sekadar untuk 
menggambarkan pengertian akan sesuatu tapi juga untuk mencapai tujuan. (Komunikator---tercapai maksudnya, dan Komunikan -memahami maksud). ${ }^{4}$

Seorang komunikator akan mempunyai dua tingkatan maksud, yaitu informatif (menyadari sesuatu) dan komunikatif (menyadari maksud). Pemilihan penggunaan new media dan memilih visualisasi satir memiliki maksud tertentu. Karakteristik new media menembus batas ruang dan waktu, relatif bebas dari aturan-aturan inilah yang membuat variasi informasi dan kritik berkembang di dunia maya ini. Mulai dari yang dikemas sangat serius, kaku, hingga yang mengkritik dalam bentuk satir karena pada dasarnya, tehnologi hadir untuk membantu manusia. McLouhan mengatakan bahwa teknologi yang diciptakan manusia adalah karena keterbatasan manusia. Oleh karena itu teknologi selalu mengandung bias. Dalam perkembangannya teknologi terkadang tidak mampu diiringi dengan perkembangan peradaban manusia, terjadi disfungsi technology dan disorientation of technology.

"... Andai ku Gayus Tambunan, yang bisa pergi ke Bali..." merupakan reff lagu yang dinyanyikan berulang menampilkan makna penekanan, sebagai sebuah pesan utama dalam lagu. Menjelaskan seni untuk menyindir moral dari seseorang, yakni satire kerap dengan menggunakan jokes dan plesetan Satire mengajak audiensi fokus pada sesuatu atau seseorang yang dianggap menggelikan dan aneh (Dustin Griffin 1994:1). Menjadi aneh apabila seorang tahanan kemudian mampu keluar dan bepergian ke tempat wisata selama masa tahanannya belum habis. Kontras dengan kondisi pelantun lagu, pada kondisi yang sama tetap harus menjalankan masa tahanan dan mendapat perlakuan berbeda dengan Gayus Tambunan.

Ketika lagu menjadi sebuah pesan, baik lirik, nada dan tampilan visualnya (melalui video klip), maka relevansi dari pesan dari lagu itu menjadi diperlukan agar mampu mempersuasif audiensnya. Komunikasi menjadi sebuah upaya untuk memodifikasi lingkungan kognitif orang lain dengan suatu cara mempengaruhi asumsi mereka atau apa yang mereka anggap benar. Menurut teori relevansi, pertama-tama konteks dipersempit berdasarkan apa yang tersedia secara seketika di dalam memori pada waktu dan tempat terjadinya komunikasi. Sebuah konteks dipilih berdasarkan upaya memaksimalkan relevansi informasi di dalam pesan. Konteks munculnya lagu ini adalah mencuatnya kasus mafia pajak Gayus Tambunan di permukaan melalui keberadaan media massa. Seakan menjadi perwujudan dari interpretasi umum tentang situsasi drama politik negeri ini, korupsi dan situasi hukum Indonesia.

Judgee Burgon dalam teori Harapan nya menyatakan bahwa semua orang mempunyai harapan berkenaaan dengan perilaku orang lain berdasarkan

\footnotetext{
${ }^{4}$ Katherine Miller, Communication Theories, Perspective, Proscess, and Contexts. $\left(2^{\text {nd }}\right.$ edn; Texas: McGraw-Hill, 2005), p. 101
} 
norma-norma sosial, sebagaimana juga pengalaman kita sebelumnya dengan orang lain dan situasi dimana perilaku itu terjadi. Aplikasinya bisa secara luas, harapan ditujukan untuk semua hal yang berinteraksi dengan manusia, juga harapan terhadap pemerintahan suatu negara. Asumsinya, ketika harapan terpenuhi, perilaku akan dinilai positif dan bila tidak terpenuhi,perilaku tersebut dinilai negatif. ${ }^{5}$

Argumentasi kognitif mengorganisasikan informasi dengan 3 cara yaitu: (1) Evaluasi, (2) Probabilitas, dan (3) Semantik. Evaluasi adalah sebuah proses dimana nilai-nilai dan penilaian diorganisasikan ke dalam sebuah pola yang konsisten. Probabilitas merupakan organisasi informasi ke dalam sebuah pola keyakinan yang konsisten,apa yang anda yakini benar. Semantik meliputi pengartian dan argumentasi bekerja untuk memelihara konsistensi dari pengartian-pengartian.

Musik bukan hanya bahasa yang dirangkai dalam artikulasi bunyi yang bisa bermakna lebih dari sekadar bunyi yang bisa mengungkapkan sesuatu. Menurut Robert Stanton, diluar sisi humoris yang identik dengannya satire juga dapat bermaksud genius sehingga sering disebut 'vitriolic' atau 'pahit'. Hal ini terjadi apabila penulis berusaha membongkar suatu kejelekan individu atau instansi, membongkar kesenjangan antara topeng dan wajah yang sebenarnya. Indonesia negara hukum, semua kasus yang terjadi semestinya diselesaikan secara hukum. Namun dalam lirik lagu maupun visualisasinya memperlihatkan betapa tampilan ketidakadilan dalam sistem hukum di Indonesia, kekuasaan dan uang adalah hukum itu sendiri. Audies melakukan pemaknaan aktif, melakukan proses argumentasi kognitif serta melakukan proses penerimaan yang nantinya akan berujung pada pembentukan sikap. Meskipun penyampaian pesn satir ini tidak dimaksudkan untuk merubah sikap seseorang, namun dengan adanya relevansi antara pengalaman akan informasi di media, menjadi sesuatu yang menarik untuk dikaji bagaimana efek pesan yang bersifat satir bagi audiens.

\title{
Lirik lagu "Andai Ku Gayus Tambunan"
}

\author{
11 Maret \\ Diriku masuk penjara \\ Awal ku menjalani \\ Proses masa tahanan \\ Hidup di penjara \\ Sangat berat kurasakan
}

\footnotetext{
${ }^{5}$ Dominic Strinati, Populer Cultur Pengantar Menuju Teori Budaya Populer, (Yogyakarta: Jejak, 2007), p. 55
} 
Badanku kurus

Karena beban pikiran

Kita orang yang lemah

Tak punya daya apa-apa

Tak bisa berbuat banyak

Seperti para koruptor

Reff :

Andai Ku Gayus Tambunan

Yang bisa bisa pergi ke Bali

Semua keinginannya

Pasti bisa terpenuhi

Lucunya di negeri ini

Hukuman bisa dibeli

Kita orang yang lemah

Pasrah akan keadaan

7 Oktober

kubebas dari penjara

Menghirup udara segar

Lepaskan penderitaan

Wahai saudara

Dan para sahabatku

Lakukan yang terbaik

Jangan engkau salah arah

*back to reff*

Biarlah semua menjadi kenangan

Kenangan yang pahit

dalam hidup ini

\section{Kesimpulan}

Lagu menjadi sebuah media kritik sosial yang berupa simbol general yang memiliki keleluasaan dalam ruang lingkup isi, karena tidak dibebani oleh aturanaturan tertentu. Meski fungsi hiburan dari sebuah lagu sangat dominan, namun sesungguhnya bisa disisipi oleh tujuan lain dari penciptanya. Menggunakan gaya satire membuka batasan yang lebih lebar lagi dari apa yang biasanya tidak mampu dilewati. Kemasan humor senjata menjatuhkan, sangat mengena bagi objek pesan satir tersebut namun memberikan hiburan bagi orang lain yang membaca pesan. Kondisi ini sangat ampuh bagi negara yang belum siap 
menerima kritikan secara vulgar ataupun untuk isu-isu sensitif, terlebih yang bersinggungan dengan penguasa. Objek satir lagu ini bukan hanya sosok Gayus Tambunan sebagai pribadi, tetapi lebih dari itu, keberadaan Gayus di lagu ini mewakili instansi tempat kerjanya, sebagai sebuah ikon berkuasanya korupsi di negara ini.

Pesan satir dalam Lagu "Andai Ku Gayus Tambunan" ini setidaknya mengangkat tiga hal penting. Pertama, tentang ketidakberdayaan masyarakat kelas proletar berhadapan dengan ketidakadilan hukum. Kedua, masalah moralitas dan skandal terselubung dari aparat penegak hukum dan pemilik kekuasaan. Ketiga, adanya hubungan antara struktur kekuasaan yang korup dengan tuntutan publik.

\section{Daftar Pustaka}

Barker, Chris. 2009. Cultural Studies Teori dan Praktek. Kreasi Wacana. Yogyakarta.

Freedman, Leonard. 2009. The Offensive Art, Political Satire and Its Censorship around the World from Beerbohm to Borat. Praeger Publishers, London

Freud, 1905. Jokes and Their Relation to the Unconscious

Griffin. Dustin H. 1994. Satire: A Critical Reintroduction Dustin Griffin. Satire: A Critical Reintroduction. Lexington: University Press of Kentucky,

Kurni, Novi. 2008. Posisi dan Resistensi Ekonomi Politik Perfilman Indonesia. Fisipol UGM. Yogyakarta.

Miller, Katherine. 2005. Communication Theories, Perspective, Proscess, and Contexts. Second Edition. McGraw-Hill. Texas

Nugroho, Heru. 2003. Menumbuhkan Ide-Ide Kritis. Pustaka Pelajar. Yogyakarta.

Ratna, Nyoman Kutha. 2009. Paradigma Sosiologi Sastra. Pustaka Pelajar. Yogjakarta.

Strinati, Dominic. 2007. Populer Cultur Pengantar Menuju Teori Budaya Populer. Jejak. Yogyakarta.

Sumrahadi, Abdullah. 2010. Menemukan Kritik Sosial Dan Kesadaran Kritis Dari Musik Rock Indonesia. Proram Doktor Sosiologi UGM. Yogyakarta.

Internet :

http://www.youtube.com/watch?v= $82 \mathrm{mLXXChKY}$ 